\title{
Vaquita: beleaguered porpoise of the Gulf of California, México
}

\author{
Bernd Würsig ${ }^{1 *}$, Thomas A. Jefferson ${ }^{2}$, Gregory K. Silber ${ }^{3}$ and Randall S. Wells ${ }^{4}$ \\ ${ }^{1}$ Department of Marine Biology, Texas A\&M University at Galveston, Texas, USA. Email: wuersig@sbcglobal.net (BW) \\ ${ }^{2}$ Clymene Enterprises and VIVA Vaquita, Lakeside. California, U.S.A. Email: sclymene@aol.com (TAJ). \\ ${ }^{3}$ Smultea Sciences, Washington Grove, Maryland, USA. Email: gregsilber2@gmail.com (GKS). \\ ${ }^{4}$ Chicago Zoological Society's Sarasota Dolphin Research Program, c/o Mote Marine Laboratory, Sarasota, Florida, USA. Email: \\ rwells@mote.org (RSW). \\ *Corresponding Author
}

The vaquita (Phocoena sinus), an endemic porpoise of the Gulf of California, México, was first described scientifically in 1958, from three skulls. It is considered a sister taxon of an ancestor of the Southern Hemisphere Burmeister's porpoise (P. spinipinnis) and spectacled porpoise (P. dioptrica), a case of antitropical distribution and speciation. Vaquita in modern times seem to have existed largely in waters 10 to $30 \mathrm{~m}$ deep of the very northern Gulf of California, and may have already existed in relatively low numbers by the 1950s and 1960s. The external appearance of the vaquita was not described until the late 1970s, and not until the 1980s and 1990s did additional information about ecology and biology emerge. Those studies and more recent shipboard and aerial visual line transect surveys, as well as stationary and boat-towed acoustic arrays, mapped occurrence patterns and approximate numbers in greater detail than before. The first credible estimates of abundance appeared in the 1990s, with numbers in the mid-hundreds and declining. While several reasons for the decline were originally postulated, mortality due to entanglement in nets has been established as the only known cause of decline, especially due to bycatch in large-mesh gillnets set for the endangered croaker fish totoaba (Totoaba macdonaldi). This fish is prized in China for human consumption of its swim bladder, generally ground up for purported therapeutic purposes. An extensive, lucrative fishery for totoaba, now illegal for many decades, has existed since at least the 1920s, and has recently increased. Although there have been laudable attempts to stem or halt totoaba fishing, these have largely been unsuccessful, and as of this writing the vaquita is on the brink of extinction. However, rapid concentrated action against illegal fishing with gillnets may yet save the species, and hope (with attendant action) must be kept alive. This overview is followed by an appendix of a previously unpublished popular essay by K.S. Norris describing when, where, and how he first discovered the species, and subsequent early work relative to this newly-described porpoise.

La vaquita marina (Phocoena sinus), una marsopa endémica del Golfo de California, México, fue descrita científicamente por primera vez en 1958, a partir de tres cráneos. Se considera un taxón hermano de un ancestro de la marsopa de Burmeister del hemisferio sur (P. spinipinnis) y la marsopa de anteojos (P. dioptrica), un caso de distribución y especiación antitropical. En los tiempos modernos, la vaquita marina parece haber existido principalmente en aguas de 10 a 30 m de profundidad en el extremo norte del Golfo de California, y es posible que ya existiera en cantidades relativamente bajas en las décadas de 1950 y 1960. La apariencia externa de la vaquita no se describió hasta fines de la década de 1970 , y no fue hasta las décadas de 1980 y 1990 cuando surgió información adicional sobre ecología y biología. Esos estudios y los estudios más recientes de transectos de líneas visuales aéreas y a bordo, así como los arreglos acústicos estacionarios y remolcados por bote, cartografiaron patrones de ocurrencia y números aproximados con mayor detalle que antes. Las primeras estimaciones creíbles de abundancia aparecieron en la década de 1990, con cifras de alrededor de cientos y en declive. Si bien originalmente se postularon varias razones para la disminución, la mortalidad debida al enredo en las redes se ha establecido como la única causa conocida de disminución, especialmente debido a la captura incidental en redes de enmalle de malla grande colocadas para la totoaba corvina (Totoaba macdonaldi), en peligro de extinción. Este pescado es apreciado en China para el consumo humano de su vejiga natatoria, generalmente molido con supuestos propósitos terapéuticos. Una pesquería extensa y lucrativa de totoaba, ahora ilegal durante muchas décadas, ha existido desde al menos la década de 1920 y ha aumentado recientemente. Aunque ha habido loables intentos de detener o detener la pesca de totoaba, en gran parte no han tenido éxito y, al momento de escribir este artículo, la vaquita está al borde de la extinción. Sin embargo, una acción rápida y concentrada contra la pesca ilegal con redes de enmalle aún puede salvar a la especie, y la esperanza (con la acción correspondiente) debe mantenerse viva. A esta descripción general le sigue un apéndice de un ensayo popular inédito de K.S. Norris describiendo cuándo, dónde y cómo descubrió la especie por primera vez, y los primeros trabajos posteriores relacionados con esta marsopa recién descrita.

Keywords: Conservation efforts; endangered; gillnets entanglement; Gulf of California; harbor porpoise; limited distribution; scientific discovery; totoaba; vaquita.

(c) 2021 Asociación Mexicana de Mastozoologa, www.mastozoologiamexicana.org 
Local tales of a small, mysterious porpoise. Although the world's smallest porpoise, the vaquita or Gulf of California harbor porpoise (Phocoena sinus), was first scientifically recognized in the 1950s, the species has likely been known to fisherfolk and Indigenous Peoples in parts of the northern Gulf of California since long before then. Interviews with local fisherfolk and long-time residents of the Gulf tell of an animal that is variously called "vaquita" (little cow), "cochito" (little pig; Brownell 1982), or even sometimes "duende" (ghost or spirit; Norris and Prescott 1961), which is likely what we know today as Phocoena sinus, although other species might also be referred to by these names. These reports, besides listing the known distribution in the northern Gulf of California, also describe the animals from much further south in the Gulf (e. g., Bahia de Los Angeles, Topolobampo; Norris and McFarland 1958; Norris and Prescott 1961), and even south to the very southern limits at the mouth of the Sea of Cortez (e. g., Islas Tres Marias, Bahia de Banderas; Norris and McFarland 1958). However, reports of vaquita further south than in the northern Gulf are likely to be incorrect (see below).

It is a sad fact that much of the history and lore of Indigenous Peoples of and near the Baja Peninsula appears to have been lost. We can imagine that the Peoples now termed Seri, Paipai, Kumeyaay, Cochimi, Cucapás, Kiliwa, and Guaycura, presently often greatly mixed with other tribes and westerners, would have wonderful recollections of a small porpoise in a vast sea (https://www.houstonculture.org/mexico/baja. html). An early unpublished attempt to investigate the vaquita and attempt to obtain a specimen, suggested that most or all of the southern reports were cases of misidentification and/or inconsistent use of the common names listed above, which are also used by some fishermen for common bottlenose (Tursiops truncatus) and common (Delphinus delphis) dolphins (Kelly 1975). The unpublished report by Kelly (1975) also suggested that two other assumptions that had been made about vaquita ecology may have been wrong: that 1) there were seasonal movements of the species south to the Midriff Islands area in summer, and 2) the species is mainly distributed in very shallow waters in and near the estuary of the Colorado River. Vaquita currently are restricted to the very upper portion of the Gulf of California, exhibit no significant migratory behavior, and occur mainly in waters about 10 to $30 \mathrm{~m}$ deep near submarine ridges often several kilometers from shore (Silber 1990a).

Scientific discovery by Kenneth S. Norris. Professor Kenneth S. Norris collected a porpoise skull in Spring 1950, while a graduate student at Scripps Institution of Oceanography in La Jolla, CA, studying several species of desert lizards. On that trip, he was mapping locations and habitat use of the Uma genus of lizards, that "lives on windblown sand" (see Appendix I, a draft by K. S. Norris of the discovery of vaquita in his own words). He found that first (for him) Phocoena sinus skull in the habitat of the zebra-tailed lizard (Calisaurus genus) among sand dunes occasionally swept by the amazingly forceful tides (and tidal fluxes of up to 5 m) of the upper Gulf of California, north of the little town of San Felipe. Norris (Appendix I) goes on to describe how this skull and two more collected by a colleague were used to establish them as of the Phocoena (porpoise) genus, probably most closely related to the Burmeister's porpoise (Phocoena spinipinnis) of South America, a wonderful example of anti-tropical distribution, as heralded earlier by $\underline{\text { Hubbs }}$ (1952) and Davies (1963) for some animals and plants of the Gulf of California region. It is also possible that vaquita derived from an ancestor of the present-day Burmeister's and spectacled ( $P$. dioptrica) porpoises (Chehida et al. 2020; Morin et al. 2020). The Norris (Appendix I) draft is a delightful recollection of his discovery, the resulting first scientific trip in 1956 to find vaquita in nature and subsequent early studies. Details describing the vaquita as a new species are in Norris and McFarland (1958).

Curiously, in the initial draft description (Appendix I), Norris does not acknowledge the probable first scientific expedition to document and photograph vaquita in nature in 1979, organized by Norris himself (Wells et al. 1981; Figure 1 , see also below), but then his recollections are in a never-before published first draft, and he likely would have elaborated as his draft developed. Since in the 1970s he advocated to us that vaquita had not been documented by scientists in nature, he may have in his draft writings accidentally confounded purported discoveries in 1956 with those that actually occurred in 1979 (Norris, Appendix I; Wells et al. 1981).

Early expeditions to find vaquita. According to Norris (Appendix I), he and colleagues sighted (probable) vaquita on their trip out of the town of San Felipe, during a short expedition in 1956. This is not represented in the published literature, but is in Appendix I. To the best of our knowledge, the first systematic survey effort dedicated to characterizing the vaquita occurred in 1979, conceived by Norris and Bernardo Villa-Ramírez, and conducted by Norris, Bernd Würsig, Randall Wells, and Benjamin López (Wells et al. 1981). Among the objectives of the survey were determining: 1) whether there was an extant population of vaquita in the Gulf, and 2) the present threats to the population. During March 3 - April 1, 1979, a survey was conducted over 1,960 km of transects through the upper Gulf, from the Rio Hardy, a distributary of the Colorado River, southward to the Midriff Islands, using a twin-engine, $7.6 \mathrm{~m}$ vessel. The survey recorded 206 sightings of 10 species of marine mammals, but only two were sightings that were probably vaquita (Figure 1). Both of these sightings occurred on March $10^{\text {th }}$, both involved two to three individuals, and both were in the northern portion of the upper Gulf in a region where most subsequent sightings of vaquita have occurred. The paucity of sightings was consistent with findings from subsequent surveys and indicative of the tenuous status of this species even 40 years ago. The surveys also noted extensive commercial fishing activities in the upper Gulf, and numerous carcasses of small cetaceans on the beaches near nets set perpendicular to shore. 


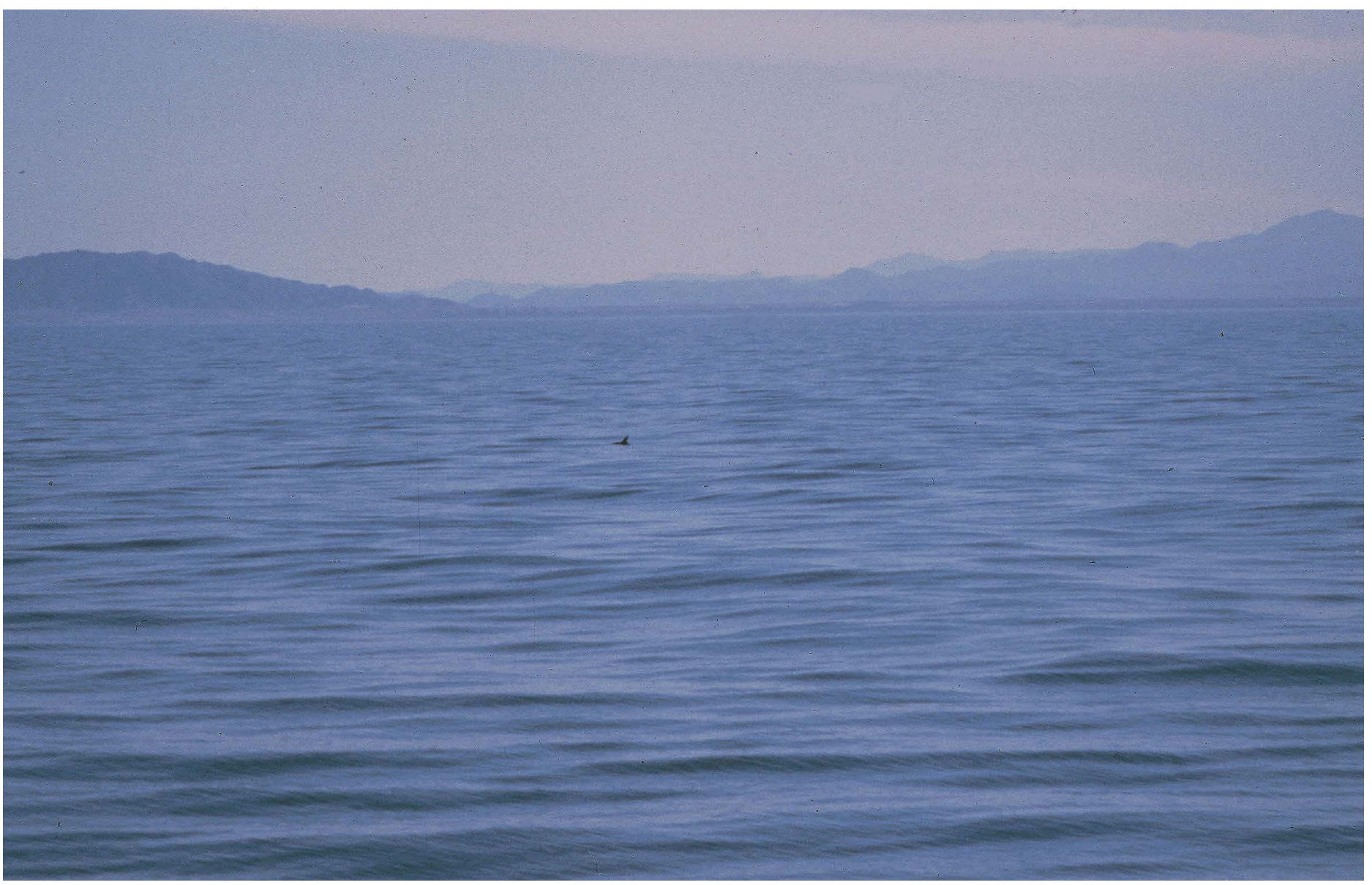

Figure 1. This is possibly the first photo published of a vaquita in nature, on a rather placid sea, taken on 10 March 1979 . Photo by R.S. Wells.

Upon reflection, while much is often made of "first discovery of", this in general means "for science", and almost always indicates re-discoveries of animals (or plants or other phenomena) long ago known and appreciated by local people. Vaquita were well known to the local fisherfolk of San Felipe, El Golfo de Santa Clara, and Puerto Peñasco, long before "we" western scientists came along. This kind of "science thinking" is outmoded, it seems to us, much as the "Columbus discovered the Americas" perspective seems ridiculous when one recognizes that the Americas were well-inhabited by humans long before Europeans came along.

Gillnetting for the croaker totoaba threatens the vaquita. The fate of vaquita may ultimately be linked to that of the totoaba (Totoaba macdonaldi), a large fish of the croaker family Sciaenidae and relative of the white seabass (Atractoscion nobilis). Like the vaquita, the totoaba is endemic to the Gulf of California. Spawners occur in the northern Gulf from December through May, with a peak January through March, sometimes in very large numbers (Flanagan and Hendrickson 1976).

Once exceedingly abundant in the upper Gulf of California during its winter-spring spawning, over-fishing severely depleted the totoaba population. The totoaba is presently listed as Critically Endangered on the IUCN Red List, listed on CITES Appendix 1, and is designated as Endangered under the United States Endangered Species Act. However, the IUCN classification is from 2010, so out of date and merits a new evaluation.

Records of commercial exploitation of the fish extend to at least the early 1920s (Craig 1926; Flanagan and Hendrickson 1976) or 1930s (Brownell 1982). Early totoaba fisheries were limited primarily to the export of dried swim bladders to Asian markets as an ingredient in gourmet soups and other uses (Chute 1928). Exports of the totoaba to the United States -- primarily San Francisco, Los Angeles and San Diego; also for swim bladder exportation to Asia -- were first reported as having occurred in the mid-1920s (see also Cisneros-Mata et al. 1995). Fishing villages in the upper Gulf grew rapidly in this period (Berdegue 1955); an estimated 200 fishermen, using mostly hook and line gear, participated in the fishery out of San Felipe alone in the mid-1920s (Craig 1926).

In this period, except for some local consumption of its meat, Craig (1926) reported there were "still many fish left to rot after their swim bladders have been removed, as the primary object of the fishery is still the manufacture of 'buche' (swim bladder)". At that time, swim bladder material was sold in Chinese markets for U.S. \$1.50-2.00 per pound. A market for its meat soon developed.

Initially the totoaba was harvested using spears from small boats and hook and line (Berdegue 1955; Flanagan 
and Hendrickson 1976). Gillnets were in use in the upper Gulf by the 1940s (Vidal et al. 1999), which may have accounted, at least in part, for an explosion of totoaba landing levels in the 1930s and 1940s (Arvizu and Chavez 1972; Flanagan and Hendrickson 1976). More than 1,200 metric tons $(\mathrm{mt})$ were harvested in all but one year from 1935 through 1946; landings exceeded 2,000 mt annually in two of those 12 years (Rojas-Bracho et al. 2013; Figure 2). Judging by landing levels for the totoaba and in other fisheries using gillnets, bycatch of vaquita must also have been high in this period.

By the 1960s, the fishery expanded to even more efficient nylon gillnets. These nets consisted of a stretch-mesh size of $25 \mathrm{~cm}$ and were generally used at a height of $4.5 \mathrm{~m}$ and were 100-200 m long (Flanagan and Hendrickson 1976). These were mesh sizes that are fully capable of entangling dolphins, porpoises, and sea turtles. Such nets are especially dangerous for porpoises in the family Phocoenidae, which often seem to have difficulty avoiding them (Jefferson and Curry 1994). Following the introduction of gillnet fishing, totoaba landings exceeding $500 \mathrm{mt}$ occurred each year from 1960 to 1970 (Flanagan and Hendrickson 1976; Figure 2). But by this time a depletion of totoaba numbers from over-fishing was probably well underway (Arvizu and Chavez 1972). Fishermen working in the community of El Golfo de Santa Clara alone had landings (in March, during peak spawning period) of totoaba that exceeded $50 \mathrm{mt}$ each year from 1964 to 1970. Yields were over $200 \mathrm{mt}$ in March 1964, 1965 and 1968 (Figure 2).
Over-fishing of the species has led to protection measures by the Mexican Government. Among these, as reported by Rojas-Bracho and Reeves (2013; Table 1), was a ban on totoaba fisheries established in 1975 (Flanagan and Hendrickson 1976), followed by another, banning totoaba gillnets in 1993. However, it is widely recognized that fishing in defiance of these restrictions often continued unabated by regulations (Rojas-Bracho and Reeves 2013; Taylor et al. 2017). One of us (GKS) observed illegal fishing activities numerous times in the mid-1990s, despite existing prohibitions, and another of us (TAJ) observed multiple cases of illegal fishing in 2006, 2008, 2010, 2013, 2015, and 2019. The IUCN Cetacean Specialist Group regularly summarizes such illegal net setting and results relative to vaquita (https:// iucn-csg.org/vaquita/, accessed 13 March, 2021).

To our knowledge, first mention in the scientific literature of the taking of vaquita incidental to upper Gulf fisheries was by Norris and Prescott (1961), as well as by Norris (Appendix I). They described occasions, as reported to them by local fishermen, of vaquita being caught in the totoaba fishery, by trawlers (that were setting gillnets), and in nets set near beaches. Some of these incidents presumably occurred in the 1950s or before. Therefore, we believe substantial vaquita bycatch levels almost certainly accompanied gillnet fisheries for the totoaba and other species in this period before the species was even described scientifically.

Dedicated studies clarify the vaquita's endangered status. Renewed interest in the study and conservation of the vaquita occurred in the mid-1980s. Key among these were

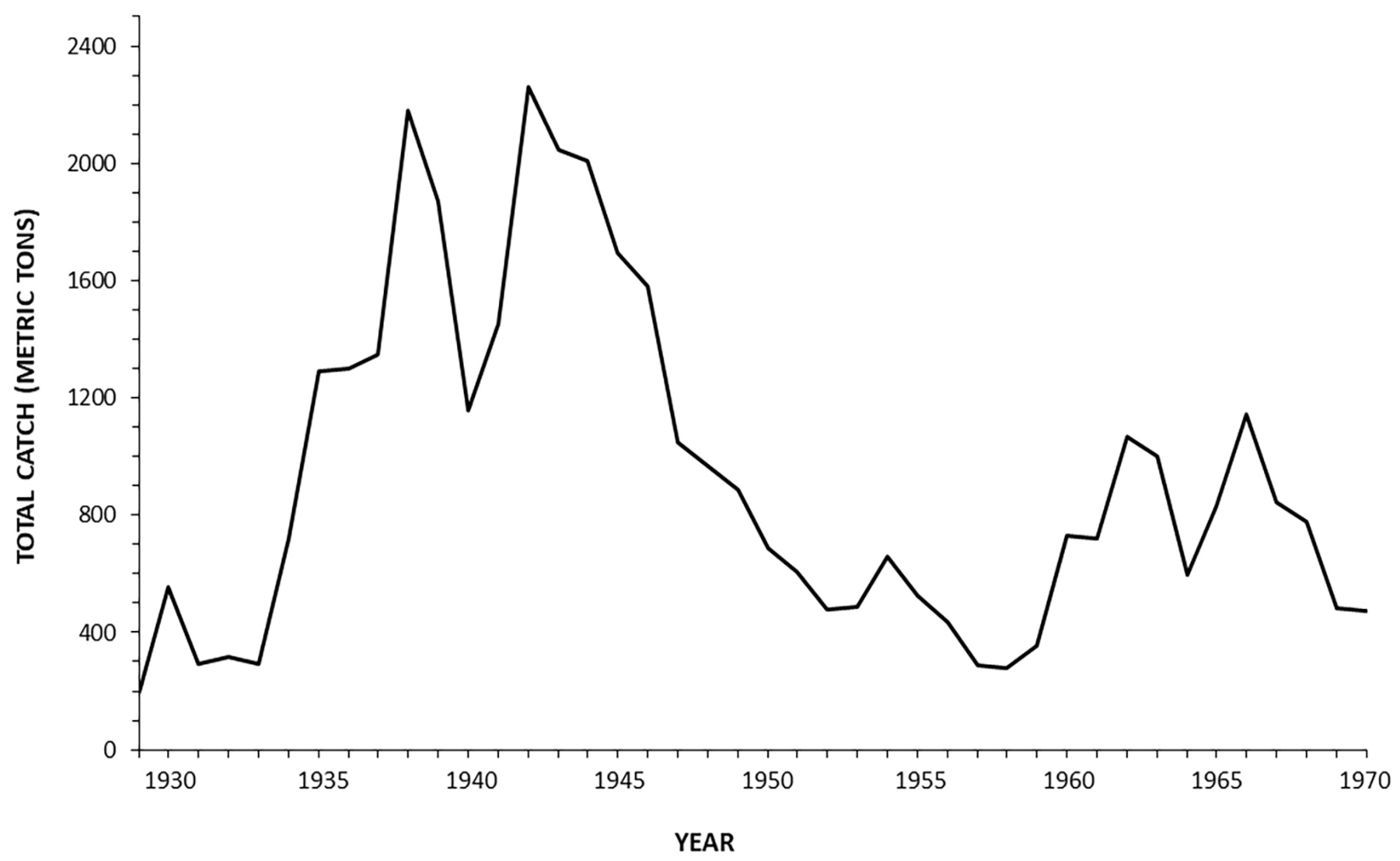

Figure 2. Yield of commercial totoaba (Totoaba macdonaldi) fishery, northern Gulf of California, 1929-1970 period. Figure modified from Arvizu and Chávez, 1972. 


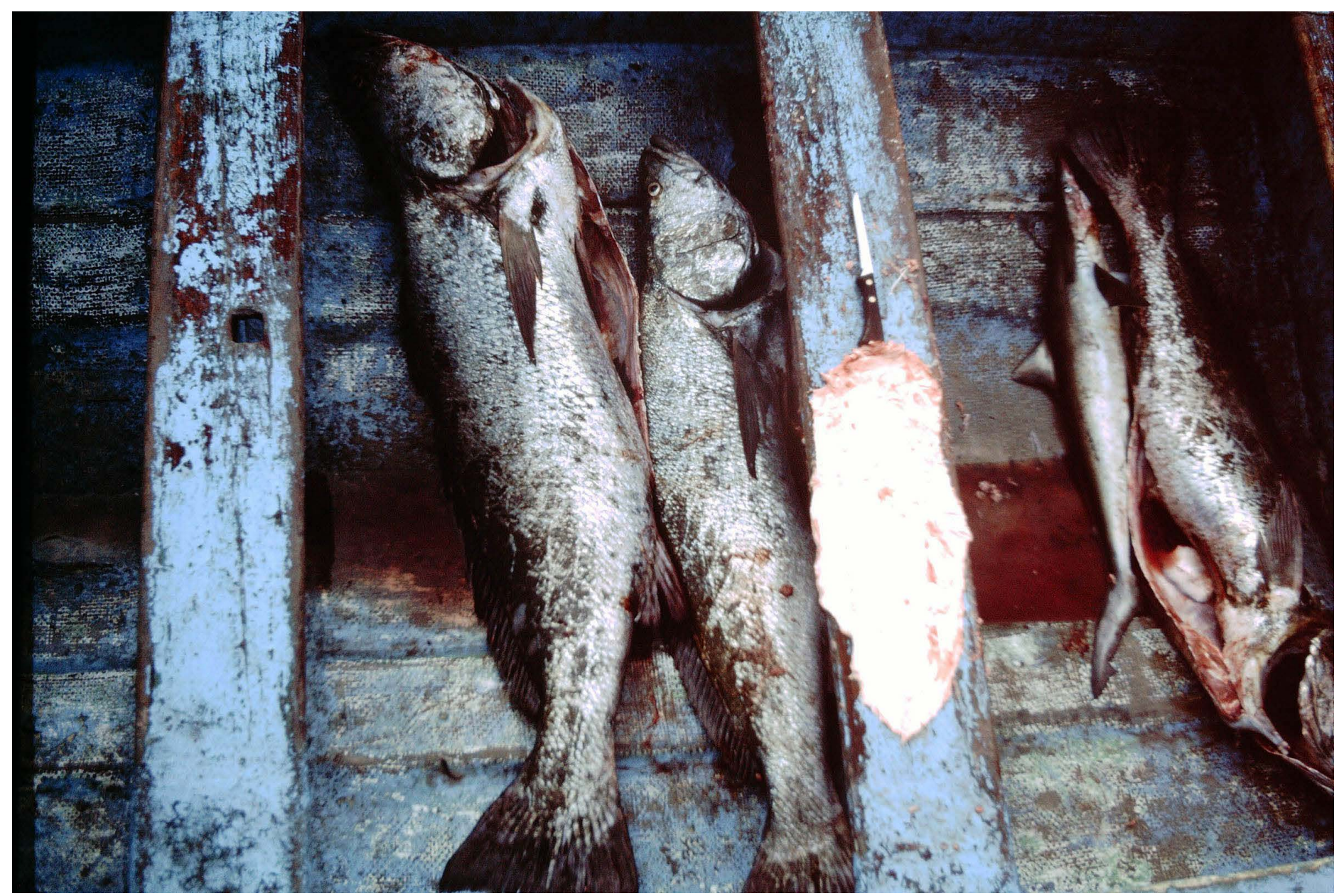

Figure 3. The sea bass totoaba (Totoaba macdonaldi) in a fisher's boat. The white tissue under the knife is of a recently-extracted totoaba swimbladder. Photo by G.K. Silber.

studies by Omar Vidal and Alejandro Robles, then graduate students at the Instituto Tecnológico y de Estudios Superiores de Monterrey-Guaymas. As a result, new information emerged on the totoaba fishery and apparent low vaquita abundance (e. g., Findley and Vidal 1985; Vidal 1993). These researchers helped focus attention on vaquita bycatch rates in various upper Gulf fisheries. For example, Robles et al. (1987) reported that 14 vaquita (four adults, nine calves, and one neonate) were bycaught in just three months in 1985 and 1986. Concerns were raised about the level of this bycatch and its impact on an already depleted population (Villa-Ramirez 1990, 1993).

In 1986-1989, Silber (1990a, b) conducted more than $1,700 \mathrm{~km}$ of surveys from a small boat and more than 1,500 $\mathrm{km}$ of surveys from an aircraft. The surveys yielded nearly 60 vaquita sightings representing an estimated total of 110 individuals sighted (Silber 1990a, b; Silber et al. 1994). Overall, sighting rates were low (approx. two sightings per 100 $\mathrm{km}$ surveyed). Nearly all sightings were concentrated in a relatively small area in the northwestern Gulf (Silber 1990b). No vaquita were seen during aircraft surveys conducted along the eastern Baja California Sur peninsula south to about 29 34' N latitude (Silber 1990a; Silber and Norris 1991), but then aerial surveys are not optimal for sight- ing vaquita (Barlow et al. 1997). These findings suggested a range that might not have exceeded several thousand square kilometers.

Additional information about the species' ecology, behavior, and affiliation with certain habitat features began to emerge from the 1980 studies. For example, 'conventional wisdom' at the time indicated that vaquita inhabited extremely shallow waters close to shore (see Kelly 1975). In contrast, new findings indicated that vaquita occurred primarily in water depths of 10 to $30 \mathrm{~m}$, at times ten or more kilometers offshore. These were areas characterized by moderate to strong currents (although still high turbidity) driven by strong tidal surges (Silber 1990a).

Habitat partitioning among several odontocete species occurring in the upper Gulf was posited (Silber 1990a). Among other things, bottlenose dolphins and vaquita were never seen in the same vicinity. Competition between or perhaps active exclusion of vaquita by the larger-bodied bottlenose dolphins from certain very shallow habitats appears likely (see Cárdenas-Hinojosa et al. 2020). Moreover, bottlenose dolphins were found almost exclusively in (often very) shallow waters close to shore, including in marshes well into the mouth and channels of the Colorado River delta (Silber et al. 1994; Silber and Fertl 1995). 
In addition, the vaquita appeared (anecdotally) to favor 'surface slicks' (Silber 1990a), a phenomenon resulting from mixing in the water column and water movement accompanying tidal ebb and flow and near submarine ridges. At these times, vaquita may have been feeding along underwater fronts, i. e., 'internal waves', resulting from moving and highly mixed water masses, again driven by substantial tidal flow. A similar use of internal waves has been reported in other cetacean species such as the harbor porpoises (Phocoena phocoena) in Monterey Bay, California (Silber and Smultea 1990) and pygmy killer whales (Feresa attenuata) in Hawai (Pryor et al. 1965).

Also occurring in the 1980s and 1990s, attempts were made to assess vaquita bycatch death rates by accompanying fisherfolks during net sets and retrievals (D'Agrosa et al. 2000), rates of recovery of net-caught vaquita (e. g., Vidal 1991), and through interviews with local fishers who were asked to recollect when vaquita were entangled (D'Agrosa et al. 2000; Turk-Boyer and Silber 1990). Estimated averages of the number of bycaught vaquita in artisanal gillnet fisheries included 15.3 individuals per year (100 between 1985 and 1990; Vidal et al. 1993), 32.3 per year (Turk-Boyer and Silber 1990), 78 per year (D'Agrosa et al. 2000), 30 to 40 per year (Vidal 1991), 58 per year (Rojas-Bracho and Taylor 1999), and tens to hundreds per year (in the 1970s; Brownell $\underline{1982}$, 1983). The D'Agrosa et al. (2000) estimate is based on statistical analysis, and the Rojas-Bracho and Taylor (1999) estimate is based on an experimental totoaba fishery, and these are likely the most reliable estimates in this list.

Studies of increasing sophistication ring the alarm bell. In the late 1990s and into the 2000s, research on vaquita occurrence and distribution became ever-more sophisticated, with visual sighting by 25-power "big eye" binoculars from large ships, limited hydrophone arrays for acoustic detections towed behind sail boats, and passive acoustic monitoring devices attached to the seafloor near suspected vaquita habitat (summarized in Gerrodette et al. 2011; Rojas-Bracho et al. 2019). The realization that vaquita could be identified and tracked as individuals from natu- ral markings (Jefferson et al. 2009) provided new options for studying their biology. As a result of such photo-identification work, it was discovered that vaquita females were capable of annual calving, something which had previously been thought not possible for this species, although it has been documented for other phocoenid species (Taylor et al. 2019; see also below). This gave new hope for the species' survival prospects.

We do not know the historical population size of the vaquita, from the period before gillnet fisheries began taking a toll on the population. The only such information comes from statistical modeling using recent estimates from vessel surveys and acoustic data, and back-calculating by incorporating information on known bycatch levels. This exercise suggests that the pre-exploitation population of the species was likely $<5,000$ individuals (Jaramillo-Legorreta 2008; Table 1). From analysis of the full genome, around 5,000 for around 200,000 years ago has also been estimated (Morin et al. 2020). As might be expected for a species with such a small and confined range, the vaquita has never been an abundant species. The earlier referenced extensive survey in 1979 (Wells et al. 1981), for example, yielded very low sighting rates relative to the survey area covered, evidence of a low abundance even at that time.

So, although the vaquita has always been thought to be a species with low abundance, there were no statistically defensible estimates for the species until the late 1980s. Barlow et al. (1997) presented the first estimates of abundance made from various methods, but all based on surveys that were somewhat compromised or incomplete (Table 1). The estimates also had high CVs, ranging from 39 to $143 \%$, and therefore had to be considered very approximate. These estimates did, however, show both that the population was small, in the hundreds (224 to 855 ), and that the species was declining (Table 1).

In the late 1900 s and early 2000 s, three ship surveys were conducted, which covered the entire range of the species, and therefore provided complete estimates using consistent state-of-the-art methods. These estimates ranging

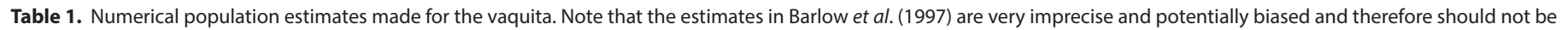
taken as evidence of an increase in numbers.

\begin{tabular}{|c|c|c|c|c|}
\hline Time Period & Estimate & Conf. Int. & $\% \mathrm{CV}$ & Reference \\
\hline Historical & ca. 5,000 & $2,088-10,697$ & nd & Jaramillo-Legorreta 2008 \\
\hline 1986-1988 & 503 & $163-1,551$ & 63 & Barlow et al. 1997 \\
\hline 1988-1989 & 855 & $340-2,149$ & 50 & Barlow et al. 1997 \\
\hline 1991 & 572 & $73-4,512$ & 143 & Barlow et al. 1997 \\
\hline 1993 & 224 & $106-470$ & 39 & Barlow et al. 1997 \\
\hline 1997 & 567 & $177-1,073$ & 51 & Jaramillo-Legorreta et al. 1999 \\
\hline 2008 & 245 & $68-884$ & 73 & Gerrodette et al. 2011 \\
\hline 2015 & 59 & $22-145$ & 50 & Taylor et al. 2017 \\
\hline 2016 & 30 & $8-96$ & nd & Thomas et al. 2017 \\
\hline 2018 & $<19$ & $6-19$ & nd & Jaramillo-Legorreta et al. 2019 \\
\hline
\end{tabular}



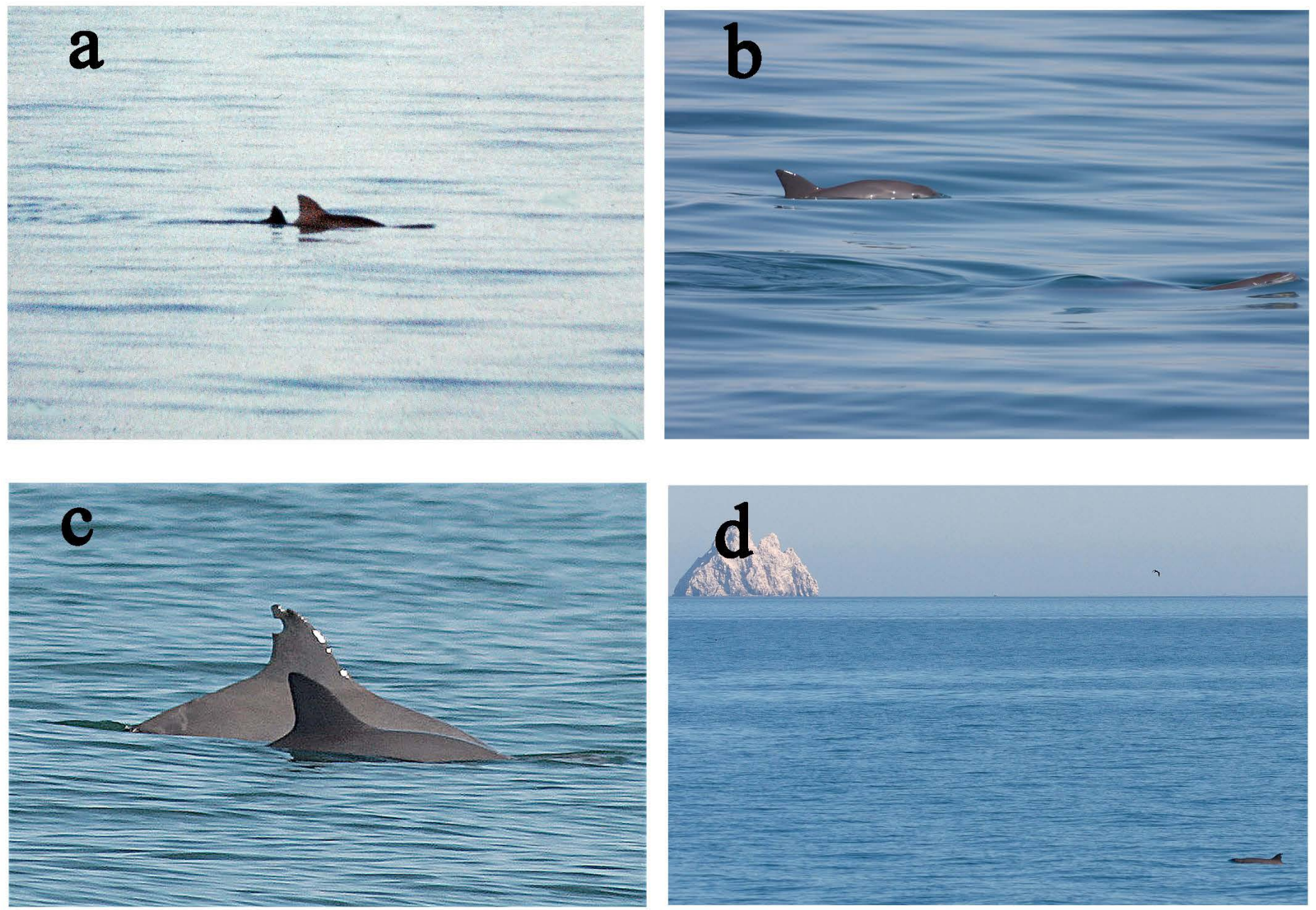

Figure 4. Progression of photographs from the 1980s through the 2000s, with modern digital photography and rapid automatic focusing of images (Figure $4 \mathrm{~b}$ - $d$ ) portraying this cryptic species as never before. The photo with Roca Consag (Figure 4d) is especially iconic for the authors, as this is near where we have seen "the most" vaquita over our lifetimes, over a deeper sea than in surrounding areas, as mentioned by K.S. Norris, Appendix I. Photos by G. K. Silber (Figure 4a) and T. A. Jefferson (Figure 4b-d).

from 567 in 1997 to 59 in 2015, confirmed with high confidence that the vaquita population was in the low hundreds, and was declining at a very rapid rate (see Table1 for statistical summaries).

In recent years, a moored passive acoustic monitoring (PAM) array of hydrophones has been used to determine trends in abundance, and these trends have been compared to abundance "anchor points" from the vessel surveys described above to determine abundance in intervening years. Bayesian statistical methods have been employed to increase precision, thereby reducing the uncertainty of the estimates. Using these methods, vaquita abundance was shown to have declined from an estimated 59 individuals in 2015 to $<19$ in 2018 (Table 1). A recent estimate suggests that there may have been fewer than 19 individuals surviving by 2018 (Jaramillo-Legorreta et al. 2019), but there is at least the possibility that this estimate was biased downwards, especially if there are individuals outside the survey study area.

High bycatch rates have probably persisted for decades; reported declines in the past two decades or so likely are not new phenomena. It is possible that animals outside the survey area were not counted, and that earlier estimates of abundance were simply too low. However, recent molecular studies appear to have confirmed that the vaquita has persisted at relatively low population levels for a very long time (Morin et al. 2020). One implication of this finding is that it is possible that harmful genetic alleles have to some degree been purged from the vaquita genome, thereby increasing the species' ability to at least partially avoid "inbreeding depression" problems often associated with very small populations. This means that it may not be too late for the species to make a recovery! However, such a positive scenario is only possible with immediate cessation of gillnet fishing in waters where vaquita occur.

Some conservation attempts. It was early on realized that bycatch in fishing nets was likely the main problem for vaquita (Norris and Prescott 1961), and Rojas-Bracho and Taylor (1999) systematically eliminated worries about large-scale habitat degradation, pollution, and low genetic diversity as major causes of decline (see also Gulland et al. 2020). Although it is not our intention here to list all conservation efforts (Rojas-Bracho and Reeves 2013 and other documents provide a thorough treatment of these efforts), a major one was the establishment of a Refuge for the 
Protection of the Vaquita in 2005 (Gerrodette and RojasBracho 2011). A large part of this eventually-unsuccessful program relied on paid support to fisherfolk and fishing communities to curtail large-mesh netting for totoaba (Rojas-Bracho and Reeves 2013). In 2008, a Species Conservation Action Plan for the Vaquita: An integrated strategy of management and sustainable use of marine and coastal resources in the upper Gulf of California (shortened to PACE-Vaquita) was promulgated by the Mexican government. Its major aims were to ban gillnet fishing in updated protected areas believed to be vaquita relative "hot-spots", promote alternative fishing techniques, and provide compensation to fisherfolk that abided by fishing bans (Gerrodette and Rojas-Bracho 2011). Although there were some early apparent successes, this too did not halt or reverse declines of vaquita. Taylor and Rojas-Bracho (2017) provided an overview of the species' conservation status in the IUCN Red List of Threatened Species, as also in Taylor and Rojas-Bracho 2020). In 2017, a major international ex situ conservation effort, under the direction of the Mexican government, was launched to attempt to remove vaquita from the dangers caused by continued exposure to gill- nets, and maintain them under human care until such time as their natural habitat was safe for them to be returned (Rojas-Bracho et al. 2019). However, the team decided to suspend capture efforts after catching two porpoises. A juvenile was released as it appeared stressed, and an adult female died of capture myopathy (Rojas-Bracho et al. 2019).

The Present Situation. The tenacity of the species to survive should not be underestimated, and this is a very strong incentive for us to not give up hope. But, we must also remember that a beleaguered species can "blink out" very suddenly. Among cetaceans, this may have been the case for the baiji (Lipotes vexillifer), which appears to have already become extinct when the first systematic and complete survey of its entire range was conducted in 2006 (Turvey et al. 2007).

In mid-2019, the vaquita was approaching extinction, with estimates of abundance of no more than 19 individuals (Jaramillo-Legorreta et al. 2019), population decline rate at about 50\%/year, and illegal gillnet fishing was still rampant in the species' range. The outlook does not look good, but there is still some glimmer of hope, as indicated by the most recent CIRVA report (CIRVA 2019), and the recent

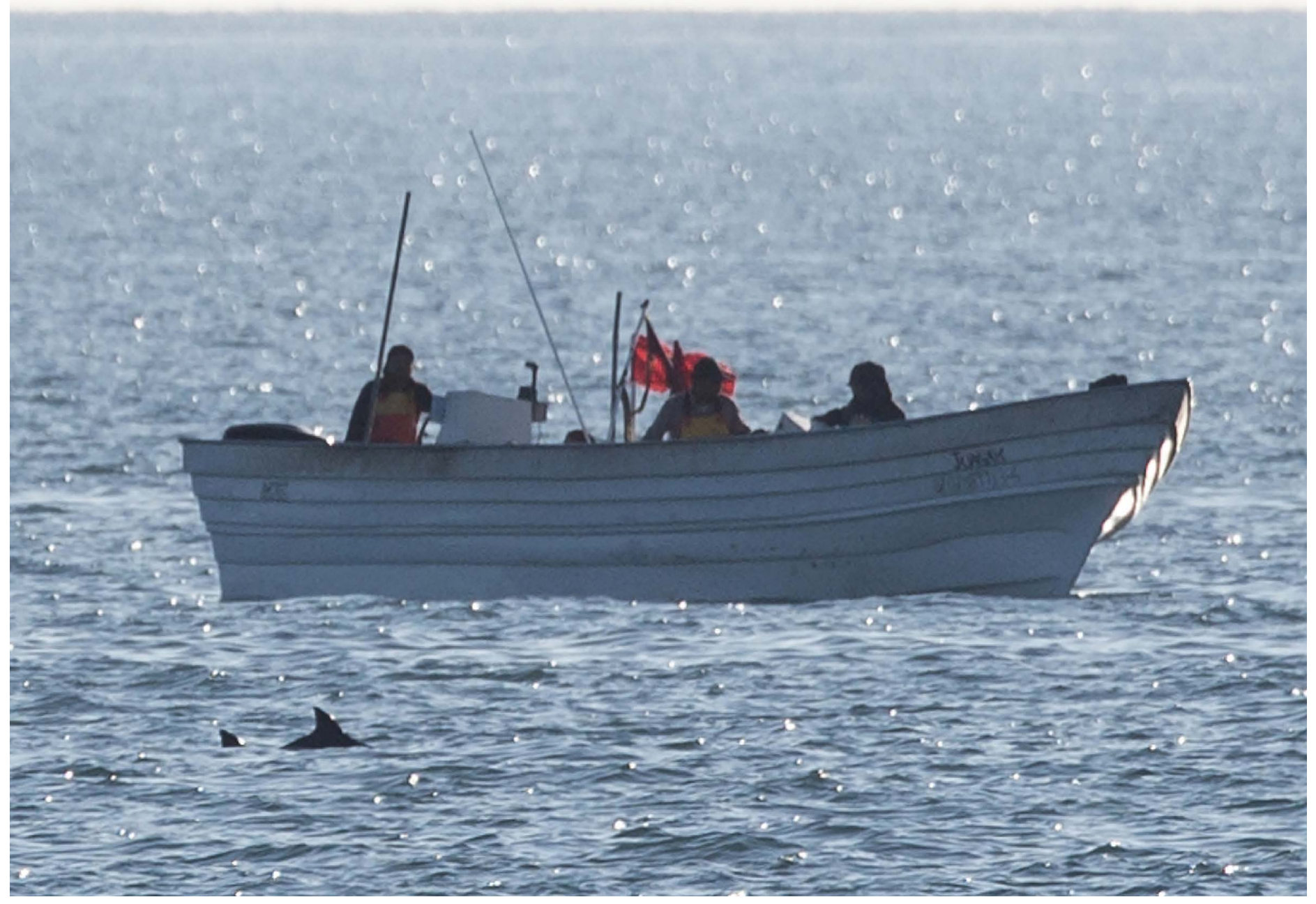

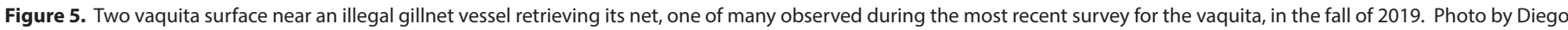
Ruiz, Museo de la Ballena y Ciencias del Mar. 
genetic findings (Morin et al. 2020). The statement in this report, that extinction for the vaquita is only months to a few short years away (if nothing changes), may be accurate. However, the remaining vaquita appear to spend much of their time in a very small area (a Zero Tolerance Zone for illegal fishing, which, if properly protected, could form an effective refuge), and are still reproducing (a fact, born out by the sighting of multiple newborns in 2019). Some of the remaining individuals bear evidence of surviving previous entanglements, based on dorsal fin scars (Taylor et al. 2019). And finally, we have realized that vaquita can give birth annually (Taylor et al. 2019), a major discovery, since previously we assumed that all females had a minimum of a 2-year inter-calf interval (see Hohn et al. 1996).

There are studies of other small and threatened odontocete cetaceans that may inform our interpretations of how best to help vaquita. One of the best studied is a little dolphin in South America. The franciscana (Pontoporia blainvillei), a species ecologically-similar to the vaquita by also occurring in medium depth waters not far from shore, is also threatened by human activities throughout its range, and continues to be taken at rates leading to unsustainable declines in abundance. Franciscanas are found in shallow coastal waters of southern Brazil, Uruguay, and Argentina, where they are exposed to artisanal fishing nets and coastal development. In the absence of empirical data, initial international management schemes suggested the existence of only four large management units across the species range (Bordino et al. 2008). In contrast, subsequent telemetry and genetic studies have determined that franciscanas instead live in small, local populations with definable home ranges, and occur in social groupings that may have much bearing on the reproductive potential for the populations (Mendez et al. 2010; Wells et al. 2013; Wells et al. in review). Concentrated removals from these small population units can have dire consequences on their continued existence. It would be good to have similar data on social groupings and behaviors of vaquita to help gauge severity of random killings due to net entanglements on their social structure and reproductive capabilities, but it is likely too late to obtain such information on the few vaquita alive at this writing.

Concluding thoughts... and a potential sign of hope. One truth apparent from the vaquita story is that species can sometimes surprise us with their 'tenacity' to survive even when projections based on best available data may suggest the opposite trend. Jaramillo-Legorreta et al. (2007), in their paper in Conservation Biology, justifiably attempted to raise awareness of the severity of the vaquita issue. The authors stated that vaquita were in imminent danger of extinction. They were correct, although the timeline is now extended towards the present, possibly because of elevated recruitment due to recently-recognized annual calving rates (Taylor et al. 2019).

Recent reports also highlight the urgent need for action, such as by CIRVA (2017), Taylor et al. (2017), Thomas et al. (2017), and Taylor and Rojas-Bracho (2020). Concerns expressed in those reports are not unlike those raised decades earlier by Norris and Prescott (1961), Villa-Ramirez (1976, 1993), Robles et al. (1987), Vidal (1995) and others. Importantly, the paper by Jaramillo-Legorreta et al. (2007) succeeded in catalyzing concern for the species and helping to jump-start needed initiatives, including the 2008 large vessel survey, which provided convincing evidence of the rapid rate of decline that gillnet fishing was causing. See also Jaramillo-Legorreta et al. (2019) for an update.

Vaquita are critically endangered by one threat, entanglement in shrimp and finfish gillnets; particularly, in the past 8 to 9 years with bycatch in gillnets due to capture of totoaba. But the human societal hurdles to overcome are several. To switch from gillnets to alternative ways of fishing and perhaps alternative ways of living, requires not only good governance and enforcement of existing laws, but also buy-in by stakeholders at all levels. A lucrative, wellorganized criminal element that subjugates the laws with extensive illegal fishing and corruption in societal and political sectors must also be addressed (Bessesen 2018 provides a general overview). What would make the greatest difference now is cessation of all gillnet fishing throughout the vaquita range, but in a manner that does not destroy the livelihood of fisherfolks, their families, and local economies. It is our strong impression that the Mexican government has not adequately enforced existing laws and this has allowed "bad actors" to set nets illegally again and again; see also Rojas-Bracho and Reeves (2013) and Taylor et al. (2017). One important avenue besides enforcement of fishing methods, is to cut off the trade of swim bladders at all levels, at towns and cities of the Gulf of California, international borders, and the marketing venues in Asia. Although ex situ establishment of a small breeding population might have been a possibility at some point, it is likely too late for that (Taylor and Rojas-Bracho 2020), and debatable whether it would be an appropriate effort to pursue for this species, given what was learned by the attempt in 2017 (Rojas-Bracho et al. 2019). See also Brownell et al. (2019) for an up-to-date description of bycatch in gillnets relative to endangered cetaceans. The most immediate threat to the continued existence of vaquita is entanglement by gillnets. This threat must be stopped. It is not only the vaquita that are critically endangered. There are many other populations, species, and ecosystems of our oceans. We need to keep hope alive, and have well-thought-out avenues for realizing potential ways to preserve species and their ecosystems (see for example Bearzi 2020; Jefferson 2019; Notarbartolo di Sciara and Hoyt 2020; Safina 2020; Würsig 2020). Gillnets and other fishing gear are the most immediate but not the only threats.

The relentlessly advancing certainty of climate change is likely threatening vaquita (Silber et al. 2017; although we do not have direct data for this), fisherfolks' livelihoods, and all of Earth's ecosystems on sea and land. We, as a species, must do a much better job of recognizing and ameliorating these very real threats to our planet's biological diversity, and ultimately to our own survival. 


\section{Acknowledgments}

We thank A. Acevedo-Gutierrez for valuable comments and for providing the Spanish abstract. We thank L. RojasBracho for his long-standing tireless efforts to save vaquita, and also for providing valuable comments. We further thank G. Bearzi for thoughtful comments in final stages of preparation. We hasten to add that any remaining errors are ours. D. Orbach kindly drew Figure 2 from original data, and $\mathrm{M}$. Würsig helped reconcile formatting issues in Appendix I from the original analog to digital version of K. Norris' draft recollections. We thank the numerous colleagues and assistants who helped our research on vaquita in the field and lab. We are grateful for the amazing contributions David J. Schmidly has made to Mexican and U.S. mammalian science, and dedicate this paper to Dave, as well as to two of his (and our) now-deceased colleagues: Bernardo Villa-Ramirez and Ken S. Norris. They are three great scientists who have bridged knowledge of many species and between two nations.

\section{Literature Cited}

Arvizu, J., and H. Chavez. 1972. Sinopsis sobre la biologia de la totoaba, Cynoscion macdonaldi Gilbert, 1890. FAO Fish. Synop. 108. Rome, Italy.

Barlow, J., T. Gerrodette, ANd G. Silber. 1997. First estimates of vaquita abundance. Marine Mammal Science 13:44-58.

Bearzı, G. 2020. Marine biology in a violated planet: from science to conscience. Ethics in Science and Environmental Politics 20:1-13.

Berdegue, A. J. 1955. La pesqueria de la totoaba (Cynoscion macdonaldi Gilbert) en San Felipe, Baja California. Revista Sociedad Mexicana de Historia Natural 16:45-78.

Bessesen, B. 2018. Vaquita: Science, Politics, and Crime in the Sea of Cortez. Island Press. Washington, U.S.A.

Bordino, P., R. S. Wells, And M. A. Stamper. 2008. Satellite tracking of Franciscana Dolphins Pontoporia blainvillei in Argentina: Preliminary information on ranging, diving and social patterns. International Whaling Commission Scientific Committee Meeting, Santiago, Chile, June 2008 SC60/SM14.

Brownell, R. L. 1982. Status of the cochito, Phocoena sinus, in the Gulf of California. Pages 85-90 Mammals in the seas, Vol. 4. Small cetaceans, seals, sirenians, and otters. FAO Fisheries Series. Rome, Italy.

Brownell, R. L. JR, R. R. Reeves, A. J. Read, B. D. Smith, P. O. Thomas, K. Ralls, M. Amano, P. Berggren, A. Myo Chit, T. Collins, R. Currey, M. L. Dolar, T. Genov, R. C. Hobbs, D. Kreb, H. Marsh, M. Zhigang, W. F. Perrin, S. Phay, L. Rojas-Bracho, G. E. Ryan, K. E. W. Shelden, E. Slooten, B. L. Taylor, O. Vidal, D. Wang, T. S. Whitty, And J. Y. Wang. 2019. By catch in gillnet fisheries threatens Critically Endangered small cetaceans and other aquatic megafauna. Endangered Species Research 40:285-296

Cárdenas-Hinojosa, G., H. De La Cueva, T. Gerrodette, and A. M. Jaramillo-Legorreta. 2020. Distribution of the acoustic occurrence of dolphins during the summers 2011 to 2015 in the Upper Gulf of California, Mexico. PeerJ. 8:e9121.

Chehida, Y. B., J. Thumloup, C. Schumacher, T. Harkins, A. Aguilar, A. Borrell, M. Ferreira, L. Rojas-Bracho, K. M. Robertson, B. L.
Taylor, G. A. Víkingsson, A. Weyna, J. Romiguier, P. A. Morin, AND M. C. Fontaine. 2020. Evolutionary history of the porpoises (Phocoenidae) across the speciation continuum: a mitogenome phylogeographic perspective. Nature Scientific Reports DOI:10.1038/s41598-020-71603-9

Chute, G. R. 1928. The totuava fishery on the California Gulf. California Fish Game 14:275-281.

Cirva (International Committee for the Recovery of the VaquiTA). 2019. Report of the Eleventh Meeting of the International Committee for the Recovery of the Vaquita (CIRVA), La Jolla, U.S.A.

Cisneros-Mata, M. A., G. Montemayor-López, and M. J. RománRodríguez. 1995. Life History and Conservation of Totoaba macdonaldi. Conservation Biology 9:806-814.

Craig, J. A. 1926. A new fishery in Mexico. California Fish Game 12:166-169.

D'AGRosa, C., C. E. Lennert-Cody, AND O. Vidal. 2000. Vaquita bycatch in Mexico's artisanal gillnet fisheries: driving a small population to extinction. Conservation Biology 14:1110-1119.

Davies, J. L. 1963. The antitropical factor in cetacean speciation. Evolution 17:107-116.

Findley, L., AND O. Vidal. 1985. La marsopa del Golfo de California. Información Científica y Tecnológica 7:15.

Flanagan, C. A., and J. R. Hendrickson. 1976. Observations on the commercial fishery and reproductive biology of the totoaba, Cynoscion macdonaldi, in the northern Gulf of California. Fishery Bulletin 74:531-544.

Gerrodette T., AND L. Rojas-Bracho. 2011. Estimating the success of protected areas for the vaquita, Phocoena sinus. Marine Mammal Science 27:E101-E125.

Gerrodette, T., B. L. Taylor, R. Swift, S. Rankin, A. JaramilloLegorReta, AND L. Rojas-Bracho. 2011. A combined visual and acoustic estimate of 2008 abundance, and change in abundance since 1997, for the vaquita, Phocoena sinus. Marine Mammal Science 27:E79-E100.

Gulland, F., K. Danil, J. Bolton, G. Ylitalo, R. Sanchez Okrucky, F. Rebolledo, C. Alexander-Beloch, R. J. Brownell, S. Mesnick, K. Lefebvre, C. R. Smith, P. O. Thomas, and L. Rojas-Bracho. 2020. Vaquitas (Phocoena sinus) continue to die from bycatch not pollutants. Veterinary Records 187:e51.

Hohn, A. A., A. J. Read, S. Fernandez, O. Vidal, and L. T. Findley. 1996. Life history of the vaquita, Phocoena sinus (Phocoenidae, Cetacea). Journal of Zoology, London 239:235-251.

HuBBS, C. L. 1952. Antitropical distribution of fishes and other organisms. Proceeding Seventh Pacific Sciece Congres 3:324-330. Jaramillo-Legorreta, A. 2008. Estatus actual de una especie en peligro de extincion, la vaquita (Phocoena sinus): Una aproximacion poblacional con metodos acusticos y Bayesianos. Ph.D. dissertation, Universidad Autonoma de Baja California. Ensenada, México.

Jaramillo-Legorreta, A. M., L. Rojas-Bracho, and T. Gerrodette. 1999. A new abundance estimate for vaquitas: first step for recovery. Marine Mammal Science 15:957-973.

Jaramillo-Legorreta, A., L. Rojas-Bracho, R. L. Brownell JR, A. J. Read, R. R. Reeves, K. Ralls, and B. L. Taylor. 2007. Saving the vaquita: Immediate action, not more data. Conservation Biology 21:1653-1655.

Jaramillo-Legorreta, A. M., G. Cardenas-Hinojosa, E. Nieto-Garcia, L. Rojas-Bracho, L. Thomas, J. M. Ver Hoef, J. Moore, B. L. 
Taylor, J. Barlow, and N. Tregenza. 2019. Decline towards extinction of Mexico's vaquita porpoise (Phocoena sinus). Royal Society Open Science 6:190598.

Jefferson, T. A. 2019. Endangered odontocetes and the social connection: Selected examples of species at risk. Pages 465-481, in Ethology and Behavioral Ecology of Odontocetes (Würsig, B. ed.). Springer Nature. Cham, Switzerland.

Jefferson, T. A., And B. E. Curry. 1994. A global review of porpoise (Cetacea, Phocoenidae) mortality in gillnets. Biological Conservation 67:167-183.

Jefferson, T. A., P. A. Olson, T. R. Kieckhefer, And L. Rojas-BraCHo. 2009. Photo-identification of the vaquita (Phocoena sinus): The World's most endangered cetacean. Latin American Journal of Aquatic Mammals 7:53-56.

Kelly, B. P. 1975. Report on a study of Phocoena sinus Norris and McFarland 1958 and an attempt to collect a specimen. Unpublished report.

Mendez, M., H. C. Rosenbaum, R. S. Wells, M. A. Stamper, and P. Bordino. 2010. Genetic evidence highlights serious demographic impacts of by-catch in cetaceans. Plos One 5:e15550.

Morin, P. A., F. I. Archer, C. D. Avila, J. R. Balacco, Y. V. Bukhman, W. Chow, O. Fedrigo, G. Formenti, J. A. Fronczek, A. Fungtammasan, F. M. D. Gulland, B. Haase, M. Peter Heide-Jorgensen, M. L. Houck, K. Howe, A. C. Misuraca, J. Mountcastle, W. Musser, S. Paez, S. Pelan, A. Phillippy, A. Rhie, J. Robinson, L. Rojas-Bracho, T. K. Rowles, O. A. Ryder, C. R. Smith, S. Stevenson, B. L. Taylor, J. Teilmann, J. Torrance, R. S. Wells, A. J. Westgate, and E. D. JARVIS. 2020. Reference genome and demographic history of the most endangered marine mammal, the vaquita. Molecular Ecological Resources 21: 008-1020.

Norkis, K. S., AND W. N. McFarland. 1958. A new harbor porpoise of the genus Phocoena from the Gulf of California. Journal of Mammalogy 39:22-39.

Norris, K. S., AND J. H. Prescott. 1961. Observations on Pacific cetaceans of Californian and Mexican waters. University of California Publications in Zoology 63:291-402.

Notarbartolo Dı Sciara, G., And E. Hoyt. 2020. Healing the wounds of marine mammals by protecting their habitat. Ethics in Science and Environmental Politics 20:15-23.

Pryor, T.A., K. Pryor, And K. S. Norris. 1965. Observations on a pygmy killer whale (Feresa attenuata) from Hawaii. Journal of Mammalogy 46:450-461.

Robles, A., O. Vidal, ANd L. Findley. 1987. La totoaba y la vaquita. Información Científica y Tecnológica 9:4-6.

Rojas-Bracho, L., AND R. R. Reeves. 2013. Vaquitas and gillnets: Mexico's ultimate cetacean conservation challenge. Endangered Species Research 21:77-87.

Rojas-Bracho, L., and B. L. Taylor. 1999. Risk factors affecting the vaquita (Phocoena sinus). Marine Mammal Science 15:974-989.

Rojas-Bracho, L., F. M. D. Gulland, C. R. Smith, B. Taylor, R. S. Wells, P. O. Thomas, B. Bauer, M. P. Heide-Jørgensen, J. Teilmann, R. Dietz, J.D. Balle, M. V. Jensen, M. H. S. Sinding, A. Jaramillo-Legorreta, G. Abel, A.J. Read, A. J. Westgate, K. Colegrove, F. Gomez, K. Martz, R. Rebolledo, S. Ridgway, T. Rowles, C. E. Van Elk, J. Boehm, G. Cardenas-Hinojosa, R. Constande, E. Nieto-Garcia, W. Phillips, D. Sabio, R. Sanchez, J. Sweeney, F. Townsend, J. Vivanco, J. C. Vivanco, and S. Walker. 2019. A field effort to capture critically endangered vaquitas for protection from entanglement in illegal gillnets. Endangered Species Research 38:11-27.

Safina, C. 2020. Psychic numbing: keeping hope alive in a world of extinctions. https: //e360.yale.edu/features/ psychic numbing- keeping-hope-alive-in-a-world-of-extinctions accessed 7 March 2020.

Silber, G. K. 1990a. Distributional relations of cetaceans in the northern Gulf of California, with special reference to the vaquita, Phocoena sinus. Ph.D. thesis, University of California. Santa Cruz, U.S.A.

Silber, G. K. 1990b. Occurrence and distribution of the vaquita, Phocoena sinus in the northern Gulf of California. Fishery Bulletin 88:339-346.

Silber, G. K., ANd M. A. Smultea. 1990. Harbor porpoises utilize tidally-induced internal waves. Bulletin of the Southern California Academy of Sciences 89:139-142.

Silber, G .K., AND K. S. Norris. 1991. Geographic and seasonal distribution of the vaquita, Phocoena sinus. Anales del Instituto de Biologia, Universidad Nacional Autónoma de México, Serie Zoología 6:262-268.

Silber, G. K., M. W. Newcomer, P. C. Silber, H. Péréz-Cortéz, And G. M. Eluıs. 1994. Cetaceans of the Northern Gulf of California: distribution, occurrence, and relative abundance. Marine Mammal Science 10:282-298.

Silber, G. K., and D. Fertl. 1995. Intentional beaching by bottlenose dolphins (Tursiops truncatus) in the Colorado River Delta, Mexico. Aquatic Mammals 21:183-186.

Silber, G. K., M. D. Lettrich, P. O. Thomas, J. D. Baker, M. Baumgartner, E. A. Becker, P. Boveng, D. M. Dick, J. Fiechter, J. Forcada, K. A. Forney, R. B. Griffis, J. A. Hare, A. J. Hobday, D. Howell, K. L. Laidre, N. Mantua, L. Quakenbush, J. A. Santora, K. M. Stafford, P. Spencer, C. Stock, W. Sydeman, K. Van Houtan, and R. S. Waples. 2017. Projecting Marine Mammal Distribution in a Changing Climate. Frontiers in Marine Science 4:413.

Taylor, B. L., AND L. Rojas-Bracho. 2017. "IUCN Red List of Threatened Species: Vaquita". IUCN Red List of Threatened Species. Retrieved 29 June, 2020.

Taylor, B. L., and L. Rojas-Bracho. 2020. The Lessons of the Vaquita. Pp. 114-116 in Shepherding Nature: The Challenge of Conservation Reliance (Scott, J. M., D. Goble, J. Wiens and B. Van Horne, eds.). Cambridge University Press. Cambridge, U.K.

Taylor, B., L. Rojas-Bracho, J. E. Moore, A. Jaramillo-Legorreta, J. Ver Hoef, G. Cardenas-Hinojosa, E. Nieto-Garcia, J. Barlow, T. Gerrodette, N. Tregenza, L. Thomas, and P. S. Hammond. 2017. Extinction is imminent for Mexico's endemic porpoise unless fishery bycatch is eliminated. Conservation Letters 10:588-595.

Taylor, B. L., R. S. Wells, P. A. Olson, R. L. Brownell, F. M. D. Gulland, A. J. Read, F. J. Valverde-Esparza, O. H. Ortiz-García, D. Ruiz-Sabio, A. M. Jaramillo-Legorreta, E. Nieto-Garcia, G. Cardenas-Hinojosa, And L. Rojas-Bracho. 2019. Likely annual calving in the vaquita, Phocoena sinus: A new hope? Marine Mammal Science 35:1603-1612.

Thomas, L., A. Jaramillo-Legorreta, G. A. Cardenas-Hinejosa, E. Nieto-Garcia, L. Rojas-Bracho, J. Ver Hoef, J. Moore, B. L. Taylor, J. Barlow, and N. Tregenza. 2017. Last call: Passive 
acoustic monitoring shows continued rapid decline of critically endangered vaquita. Journal of the Acoustical Society of America 142:E512-E517.

Turk Boyer, P. J., AND G. K. Silber. 1990. Estimate of Vaquita, Phocoena Sinus, mortality in gillnet fisheries in the northern Gulf of California, Mexico. Report submitted to the Center for Marine Conservation. Washington, U.S.A.

Turvey, S. T., R. L. Pitman, B. L. Taylor, J. Barlow, T. Akamatsu, L. A. Barrett, X. Zhao, R. R. Reeves, B. S. Stewart, K. Wang, Z. Wei, Z. Zhang, L. T. Pusser, M. Richlen, J. R. Brandon, and D. WANG. 2007. First human-caused extinction of a cetacean species. Biology Letters 3:537-540.

VIDAL, O. 1991. The vaquita: extinction is forever. Baja Explorer 1991:10-11.

VIDAL, O. 1993. Aquatic mammal conservation in Latin America: Problems and perspectives. Conservation Biology 7:788-795.

VIDAL, O. 1995. Population biology and incidental mortality of the vaquita, Phocoena sinus. Reports of the International Whaling Commission Special Issue 16:247-272.

VIDAL, O., R. L. Brownell, AND L. T. Findley. 1999. Vaquita Phocoena sinus Norris and McFarland, 1958. Pp 357-378, in Handbook of Marine Mammals, Volume 6: The Second Book of Dolphins and the Porpoises (Ridgway S. H., and R. Harrison eds.). Academic Press. London, England.

Vidal, O., K. Van Waerebeek, and L. T. Findley. 1994. Cetaceans and gillnet fisheries in Mexico, Central America and the Wider Caribbean: A preliminary review. Report of the International Whaling Commission 15: 221-233.

Villa-Ramirez, B. 1990. La vaquita, Phocoena sinus, una especie agonizante. Revista de la Universidad Nacional Autonoma de México 45:6-8.

Villa-Ramirez, B. 1993. Recovery plan for the vaquita, Phocoena sinus. Report to the Marine Mammal Commission.

Wells, R. S., B. G. Würsig, AND K. S. Norris. 1981. A survey of the marine mammals, including Phocoena sinus, of the upper Gulf of California. Report to the Marine Mammal Commission, NTIS PB-81-168-791.

Wells, R. S., M. J. Cremer, L. G. Berninsone, D. Albareda, K. A. Wilkinson, M.A. Stamper, R. L. Paitach, and P. Bordino. In review. Movements and behavior of franciscana dolphins (Pontoporia blainvillei) off Argentina and Brazil: Considerations for conservation. Frontiers in Marine Science, Section Marine Megafauna, Small Cetacean Conservation: Current Challenges and Opportunities.

Wells, R. S., P. Bordino, and D. C. Douglas. 2013. Patterns of social association in the franciscana, Pontoporia blainvillei. Marine Mammal Science. 29:E520-E528.

WürsiG, B. 2020. From science only to science for conservation: a personal journey. Ethics in Science and Environmental Politics 20:25-32.

Associated editor: Lisa and Robert Bradley Submitted: January 9, 2021; Reviewed: March 3, 2021

Accepted: March 24, 2021; Published on line: May 28, 2021. 


\section{Appendix 1}

Draft Chapter by Kenneth S. Norris, deceased 1998. Ken wrote this in the early 1990's, but did not have an opportunity to finish it as part of a book. We reproduce it here, in first draft, even with minor errors; but Ken's first draft words were much better than many people's final writing. We took the liberty of correcting some typographical errors and have provided footnote annotations, where appropriate, to clarify some passages.

Please read carefully and enjoy. It is a naturalist's journey delight (printed with permission by and with the courtesy of Ken's son, Prof. Richard Norris, Scripps, UCSD).

Signed with love by the authors and dear friends of Ken, BW, TAJ, GKS, and RSW.

Here now from Kenneth S. Norris:

Vaquita

The flame of an era flickers down. Though now it is likely that only a handful of whales and dolphins remain undiscovered, it was a different story only just three or four decades ago. All through the 1800 s and well into our century, cetologists did mostly two things. They studied cetacean anatomy, usually by doing painstaking dissections of beached animals. The other activity was biological bookkeeping, or systematics. How many kinds of these animals are there? What should we call them? Where are they found?

It may sound dull, but it wasn't. Imagine discovering a new mammal, one unknown to science. For the first time in the history of the earth this animal had been discovered by man. If you described and named your find, you and the animal became linked forever. "My dolphin", you thought, full of proprietary feelings for this critter swimming out there in the ocean, who hadn't the slightest idea about you.

The beach was the usual source, and the prize frequently reeked with decay and dripped with fetid oil. Someone had phoned, a lifeguard or a policeman. Typically, such calls came just as dinner was put on the table.

"There's a dolphin on the beach. You're the dolphin guy aren't you?" Those who study whales, dolphins and porpoises. I learned to my surprise that I was one.

"Where is it, and what does it look like?" The decision was usually made to check it out before the tide came in again. And off we cetologists went, half loving the possibility of a prize, a rarity, and half wanting to stay home by the fireplace, with a glass of wine.

"Put on your coveralls and rubber boots" said the wife, a voice of experience who had had a pungent, blood-and-oil covered husband burst in the house before, with a heedless "Guess what it was, honey!, as incredibly ugly boots and coveralls were pulled off in the pantry.

Once near the beach the wine and the fireplace were forgotten. All that was swept away by the scene; the wind, the waves purling up on the darkening strand, the birds swooping, and far down the beach, a knot of people standing looking down at something, surely the stranded animal.

I sidle into the crowd, look down and at a glance make out the curious, overhanging snout of a pygmy or dwarf sperm whale- a rarity cast in from the abyssal ocean. I say: "Kogia." The knot of people hear the unfamiliar word, and note my boots, clothing and measuring gear. "What is it?" they ask, having found a voice of authority in their midst.

Every once in a while, though, identification is not so simple. It may then take real sleuthing to find out what was lying there on the sand. I'll tell you now about the first such discovery I ever made. It was of the vaquita or Gulf of California Harbor Porpoise . I had collected the first specimen of this little animal well before I began in earnest to learn about either fish or cetaceans.

It was a spring day in 1950. I was savoring the brand new, high-bermed gravel road to San Felipe, Baja California, México. The old road that it had replaced had been a thing of legends. Even though it was the lifeline between the trading center of Mexicali and the fishing village of San Felipe on the upper Gulf of California, the old road was no more than a winding, two-rut track that, against all the dictates of reason, transected the periodically flooded salt pan at the entrance to the Laguna Salada, a huge, soggy lake bed usually glittering with salt. When the surging spring tides of the upper Gulf (some topping 30 feet at the crest) came sweeping across the vast, vegetationless mudflat from the Gulf of California to the east, the road sometimes disappeared utterly and became a miles-long wallow of bottomless mud. That was half of the problem. The torrential rains of summer frequently achieved the same end as they flooded down the barren Sierra Cocopah, sluicing mud and boulders across everything in their path. When one or the other happened the market town of Mexicali and the fishermen of San Felipe were on different planets. It was weeks before the first intrepid truck to Mexicali swam its way through again.

I was nearing the end of a two-week scientific trip alone across the southwestern deserts and could feel the terminal nervous stage coming on. That's when I checked my gas tank three times a morning. I was making a desert-wide map of the dunes on which a certain species of lizard lives. 
I had one more dune to check, one just north of Punta San Felipe. The lizard I sought, a beautiful little animal called Uma, lives only on windblown sand dunes. I'd wondered how they got between the widely separated dunes if, as they were thought to do, they always stayed on wind-blown sand. I'd plotted the several dozens of dunes where the lizard had been found and discovered that I could link most of them by proposing sand corridors along stream courses or over low divides, and by relating the development of dunes to past climates as the Ice Age had left the desert. But Punta San Felipe was 60 miles south of the last dune on which Uma was known to live, and a stony, flood-washed desert intervened.

According to my theory Uma shouldn't be there. As my truck jounced along over the newly laid gravel I could see the flat, blue Gulf of California far down the bajada. Then the hazy, purple headland of Punta San Felipe materialized along its shore. I knew that on the south side of that point lay the dusty little fishing village itself.

I rolled my window down to let in the balmy desert air and sang as loud as I could, not because I was thinking of Burma, or lissome maidens, but because I was alone and on the last lap toward home.

"By the old Moulmein pagoda Looking eastward to the sea, There's a Burma Girl a'sittin, And I know she thinks of me."

A few years later when I sang that song in a family-filled station wagon my little daughter Barbara would clasp her hands over her ears and cry: "Daddy, daddy, too loud!!"

No volume control this time, though. I could see the dune, a pale pinkish splotch stretching north behind a curving beach. I turned off the gravel berm and onto a jouncy two wheel track.

"Ohh the wi-i-ind is in the-e pa-aim trees."

The trail shied this way and that around the bases of big clumps of creosote bush and palo verde, both alight with the yellow flowers of spring and attended by the loud hum of thousands of bees. The track ran down long stretches of open wash, which I assessed with a practiced eye. My decision was whether or not, on my way back uphill I was likely to sink into the gravel and bog down. The slightly damp sand told me I could make it if I kept my speed constant and didn't spin my wheels.

In half an hour I pulled to a stop at the edge of the flat salt pan behind the dunes, pulled my hat down against the growing power of the sun, and began to walk along the dune margin. The dune was heaped between the sea and me-clean sweeps of immaculate, pale pink sand piled by the wind in lovely arcs. It wasn't long before I had my answer about the sand lizards.

No Uma's here. Their ecological space, up on the open sand, and in the little hollow valleys between dune crests called blowouts, was occupied by another lizard, the sometimes extravagantly beautiful Callisaurus, or zebra-tailed lizard'. I'd learned that Uma and Callisaurus, in some unknown way compete for habitat, and that Uma, when it is present, is the winner on open sand.

The male zebra-tails were posturing when I arrived, probably jockeying for space. I hid behind a creosote and watched one light-footed encounter, two lizards in a circling dance, going almost taster than I could follow, spiraling off across the flat.

As I walked the dune margin, I saw a whitened skull partly protruding from the sand, buried just above the reach of the usual high tide. The flooding sea had coursed around the dune and over the pickleweed flat, filling long ponds back of the dunes. Anything that floated- paper boxes, bits of wood, scrub brushes off of fishing boats, animal carcasses- was borne in, tumbled by the wave swash, and then left when the water receded. This skull was all that remained after the coyotes and mice had cleaned it. I couldn't identify it, except to say that it was obviously a very small porpoise or dolphin.

I picked it up, shook the sand out of the brain case, and carried it back to the truck. That night after dinner I sat on my cot under a circle of light from the hissing Coleman lantern and wrote out a specimen tag for the skull. I tied it on carefully, using a good square knot, and then I wrapped the skull in newspaper and stowed it away in an empty carton. I thought little more of it. It didn't even warrant a line in my journal.

Three years later a paleontologist friend, Dr. Jim Warren, brought me two more skulls from the beach a short distance south of San Felipe. They were of the same little animal from the same general place. There really was a tiny cetacean down there, and so far as I could learn, no scientist knew about it!

By then I was busy in my curator's post, with $\mathrm{Mac}^{2}$ running the vital little laboratory that attempted to develop answers for the cloud of questions that descended upon us. Why, for example, was the water in the big fish tank cloudy this morning? Why had a trigger fish died? Mac can build anything, knows all sorts of stuff I don't, will bray in indignity when somebody does something stupid, and is first to pick up whatever needs to be picked up. Everything we did together became a shared high adventure, not a boss and employee thing. "Hey Mac, why don't we try this?..."

Mac and I were both finishing our doctoral degrees in absentia; he at UCLA and me at Scripps Institution of Oceanography, so under our leadership the Oceanarium's lab took a real scientific turn. It became an exciting place of discovery.

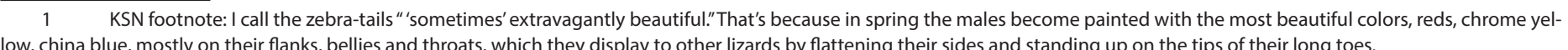
low, china blue, mostly on their flanks, bellies and throats, which they display to other lizards by flattening their sides and standing up on the tips of their long toes.

2 We assume that this refers to William N. McFarland, with whom KSN wrote the species description published in 1958. 
To my surprise I found that very few careful observations of Pacific dolphins had been made, and here we were working with them daily.

Scientists barely knew what kinds of dolphins and whales lived off the California shore, even a few miles from the Los Angeles Harbor entrance, let alone what they did. The seasonal comings and goings of the various species, how many there were, what they ate, how they swam and dove were all nearly a complete blank. Terra incognita Swiss Family Robinson! Mac and I were in a biologist's version of Hog Heaven!

To instill some order in all this treasure I designed a scientific contribution series for the oceanarium. It was planned as a collection of scientific reports about the best of our discoveries. We'd staple a special cover with a dolphin printed on it to every new report, advertising "Marineland of the Pacific Laboratory Scientific Contribution No. --". By the time I left the oceanarium for a University post we had produced dozens of such papers, and our little dolphin logo graced a good many library collections.

Contribution Number 1 in our series was a collection of behavioral observations of the cetaceans of southern California waters made while we were out collecting. We just edited and arranged our field notes and voila! there was a worthy contribution to the knowledge of California's wildlife.

I showed Mac the Gulf of California cetacean skull. Maybe this little guy would be a good subject for Publication No. 2?

"Where do we start, Mac?" I asked.

"Identify it, of course, dummy."

"I knew that, Mac! I replied, with a bit of pain in my voice.

But 'we put the skull in my car and drove to the University of California at Berkeley, where the major scientific collection of western United States vertebrate animal specimens is housed. One didn't just knock and enter the Museum of Vertebrate Zoology, either, especially two untested graduate students didn't. Both courtship and obsequiousness were involved. Furthermore, we were both from lesser institutions at the south end of the state, a factor that loomed large in 1953.

A suspicious schoolmarmish lady recited the numerous rules of MVZ toward the precious materials in the collection, and then led us to the zinc cabinets where the specimens were housed. Those cabinets were not ours to open, either. We watched while the curator picked out this or that specimen as if it were Dresden, and placed it on a big, open table for us to look at. He watched us while we compared our skull with others in their collection, and then antiseptically replaced the specimen in its vault.

An older man, foppish and dapper, slid behind us. Peering over our shoulders as he went by.

"What's the genus of your skull?" He queried, as if he was giving a final exam.

"That's what we are here to find out." I replied, a little cowed. After a long, almost theatrical pause, he said:"Phocoena."

"What does the Latin name mean?" He then asked. I hadn't the slightest idea, nor did Mac. "It's Greek for Porpoise" he replied, detaching his thumbs from his weskit and moving on.

It was Dr. Seth Benson, who was reputed to know nearly everything. Undaunted, as good graduate students often are, we turned back to our skulls. Mac's and my social sense at the time scarcely recognized that while we had written ahead for permission to examine the collection, we still remained two graduate students who didn't know the genus of one of the best-known of cetaceans in the United States!

Benson was right. The little skull was from a specimen of Phocoena. In the following days Mac and I dug out everything we could find on the genus.

Phocoena. We found that Phocoena was the name of the common porpoise, and that England's Queen Elizabeth was reputed to have considered it a delicacy. Phocoena ranged widely around the shores and bays of the temperate and subarctic Northern Hemisphere. In some places it was called the puffing pig, in others the herring hog. We learned that one can tell modern porpoises from dolphins because they usually have very low triangular dorsal fins, little cusped teeth (instead of conical ones), blunt snouts, and more easily movable cervical vertebrae than the dolphins do.

A lot of wonderful history emerged from our sleuthings. The Swedish botanist, Carl von Linne in his 1758 Systema Natura, his great attempt to classify all living things, had named the little cetacean "Delphinus phocoena." Since everything he wrote was in Latin he changed his own name to Linnaeus, which is what most people still call him today. ${ }^{3}$

In $1817^{4}$ Baron Jean Léopold Nicolas Frédéric Cuvier (how lovely it must be to have all those names and all those accent marks in one's name!) recognized the genus Phocoena as different from the dolphins and there it remains today.

The more we searched the more we became convinced that our little critter was not the common porpoise of the Northern Hemisphere but an unrecognized species. Even though our three skulls were from adults (you can usually

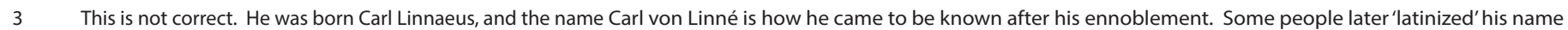
as Carolus Linnaeus.

4 The correct date is 1816. Cuvier's full name has been corrected from that of KSN's draft.
} 
tell an adult mammal by its skull because the sutures between the skull bones are fused) the porpoises were tiny compared to other cetaceans. We later learned that this little cetacean is, in fact, one of the world's two smallest-its nearest rival is a spinner dolphin that lives in the Gulf of Thailand.

What convinced us that we had a new species were several features of their skulls-little details that were different from the general run of puffing pigs. Proving such a contention involves description, precise measurements of all the specimens one can muster, and statistical analysis of the results. It's not work for the flighty and it took us months.

We began to realise that our little animal was closest to a South American Phocoena, a curious almost totally black animal with a cut-off sloping dorsal fin studded with a double row of little horn-like prickles. It is called Burmeister's Porpoise, or Phocoena spinipinnis.

Aha! Mac and I suddenly realized that somehow, sometime, the ancestors of Phocoena had crossed the equator! How, when? Which way?

We didn't have to look far. My professor, Carl Hubbs at Scripps Institution had been there before us. In a seminal paper on the subject he had written of antitropical species, and there were many.

These are creatures that had somehow jumped the equator and now occur on both sides of the tropics, either as the same or closely related species. He wrote of anchovies, kelps, jack mackerel, dolphins, and a good many other fish and invertebrates that obviously had done this. There was even the huge sleeper shark, Somniosus, that today is distributed under the warm surface waters of the tropics. This ancient creature is seen among the ice floes of the Arctic, and there has even been reported attacking walruses, but it has also been identified from photographs taken in deep water beneath the warm surface waters of the tropics, where it never ventures to the surface.

Mac and I asked next: "When and how had all these animals made the trek across the equator?"

The most likely time for this porpoise ancestor to have swum across the Equator, it seemed, was during the recent Ice Age, which placed the crossing from a few thousand to perhaps two million years ago. Judging from fossils, most modern species of dolphins and porpoises have been around for several million years, and the skulls of the two species from opposite sides of the equator are pretty similar. The "feel" was of a fairly recent separation.

"What happened to the tropics during the Ice Age? I asked Mac, while I thumbed through a text on ocean history. "Hey, look at this!"

Down near the Equator, in the general latitude of the Panamanian Isthmus, the Caribbean and eastern Pacific waters are very different. On the Caribbean side at latitude $0^{\circ}$, one finds coral reefs and clear, warm water with many tropical species swarming about. On the Pacific side, however, things are very different. The water tends to be a bit murky and on average it is much cooler. The animals that live in the Pacific tropics are a very different collection of species, too. A cool water corridor all but exists today across the tropics! The cause of all this lies in the different ocean currents of the two oceans.

The enormously long ocean currents that rim the eastern Pacific, the California Current of the Northern Hemisphere, which sweeps south along the west coast of the United States and the Humboldt Current of South America, which flows northward along the shores of Chile and Peru- both, as they near the tropics, begin to bend due westward across the mid Pacific toward Asia. A thousand miles off the Central American shore they come to run parallel, to stream clear across the ocean side-by side, two "rivers" going the same way but separated by a countercurrent coming back toward the Western Hemisphere. Before these currents bend west, one north and one south, they trap between their conjoining arms a triangle of cool water that lies against the shoreline of Central America. It is this water that supports all those cool water species I just mentioned.

Maybe this cool triangle of shore water, made even colder during the Ice Age, was the corridor that our little porpoise required to cross the new world tropics. Burmeister's porpoise lives today as if poised for such a swim, since it is found in the chilly Humboldt Current right up to the Equator in northern Peru.

Finally, Mac and I decided to name the little porpoise Phocoena sinus, the Gulf of California Harbor Porpoise." Sinus is Latin for "Gulf." A nice, neat comprehensible little name, we thought.

"O.K., Mac?" I said, let's go see a live one! We wanted to talk to fishermen who doubtless knew about the little porpoise, and we wanted to keep our own watch looking for fins. On our collecting schedule were trips to the upper Gulf of California to collect some of the many interesting fishes that live there, especially the giant six foot white sea bass, thetotoaba. With a little luck we might see our porpoise at the same time.

Our plan was to hire totoaba fishermen out of San Felipe to catch three or four specimen fish. We planned to hold these big fish in a "live car," a specially built decked over skiff with doors in the side, which we could tow behind a fishing vessel and through whose side door any big fish could be led. Then we would attempt to haul our huge catch back to the oceanarium at Los Angeles. For this job Mac and I had designed, and Frank and Boots had built, a special fish transport tank that we could 
load on the oceanarium's biggest truck for the drive to México and back; its 26,000 pounds of circulating sea water being pumped through aerators to keep the fish alive.

So, one spring day in 1956, the four of us, our truck, fish tank and live car hauled into San Felipe. The first stop was to find a base camp for the expedition. Frank began a process that he called "snootin' around" among the local fishermen. Soon he located a roofless cinder block building that we were able to rent.

"If you are in a foreign place, buy into the local economy if you want to be taken care of", was Frank's wise rule. Though the building had doors that we could lock, providing the illusion of security, it was the owner from whom we rented that mattered. He, as Frank predicted, made sure that no one tampered with his chance to earn money from the gringos.

We christened the tumble down edifice "The St. Frances Hotel", swept out the considerable trash, and moved in. Soon the spaghetti water was steaming on the gasoline stove and a squadron of local dogs began circling-a formation that would last as long as we were in occupancy. After our meal, gear was laid out for the next day's fishing and then we crawled into sleeping bags under a starry sky that shone down where a roof ought to be.

Before dawn Frank was up making a pot of coffee. We four drank it standing up, and then made our way down to the dark strand flashing with star flicker. The spring air of San Felipe, even that early in the season, can be soft and warm enough to bathe in. Offshore, a short row away, lay a venerable fishing vessel San Luis, rocking in the low swell, a rust bucket whose hull next season would part peacefully and sink at anchor to the bottom of San Felipe Bay. We all knew it was coming. One had only to lean on a rail and have a piece of it come off in your hand to know that. But it was what these fishermen had and everyone took their chances, we included.

Captain Fortunato Valencia was already on board, warming up the engine, and Olaya the cook took up his position straddling the gaping hole created by the missing engine room hatch, bare feet gripping the hatch combing on either side, and began cooking breakfast- potatoes and bacon that we had provided. Down, six feet below his crotch the rocker arms of the old diesel had begun to click methodically. This arrangement had something to do with providing air both for the engine and the engineer.

In addition to breakfast makings, Frank left Olayo a tinned ham to work on for the evening meal. Later that day I came by Olayo's deckless galley to find him gripping the slippery jelly covered ham with his toes. Those toes, I could see, were crucial organs for a person with his job. He had the ham pinioned in an angle of the galley deck, and there he sliced off pieces with a long butcher knife. These were dexterously retrieved before they fell on the diesel engine. Olayo seemed to regard all this as ordinary.

Thus splayed across the galley he spoke to me of his twelve children ashore. The San Luis, he implied, was a peaceful place by comparison, and he was happy to be with us. The big screw swirled and we left the harbor, the sea as calm as if it had been oiled. We headed for the totoaba grounds off Punta San Felipe. An hour or so later the vessel slowed to a stop. I looked to the west and could see the pale dunes where I had pulled the type specimen of Phocoena sinus from the sand six years before.

A small group of tiny cetaceans- the largest about five feet long- broke water. I asked Fortunato to take us closer. Soon I could hear the puffs of their breaths, and could make out the blunt head of one. Such tiny clues, which we had learned from our reading, all suggested that they were porpoises, not dolphins.

The little mammals didn't school tightly together as dolphins usually do, but dove raggedly and headed in different directions underwater.

"Those are our porpoises, Mac!" "For sure," replied Mac.

Another curious thing struck us, and has since been seen by other more recent observers. The Northern Hemisphere common porpoise can be identified at once by its low, broad-based dorsal fin, shaped like a flattened triangle. If you see a cetacean with such a fin in North American waters, you can be pretty sure it is attached to a porpoise. Yet one of the little Gulf animals that swam off our beam had a tall fin, almost like a little killer whale.

Later I proposed that this has to do with the very warm water of the Gulf in summer. The shallow upper Gulf may turn to warm soup under the implacable desert sun, the water pushing into the $90^{\circ} \mathrm{F}$ range. This means that a little mammal, immersed in such a tepid sea with no way to seek shade, has at most about ten degrees difference between its body and the water to work with should it seek to escape a predator or catch a fish.

That translates to lassitude, or to a very small "scope for activity" as the physiologists call it. That tall fin is a porpoise's heat exchanger. If the porpoise exerts itself blood pours into special vessels just beneath the skin of the fin to dump the excess heat into the passing water. The bigger the porpoise the larger fin surface it requires to cool itself; so, reasoning backward, a large fin must also mean a large porpoise. Parenthetically, I think this is also why old bull killer whales have huge, disproportionately large fins compared with their much smaller female consorts. Scientists frown on these circles of logic, and rightly so, but they can be wonderfully useful to pose conundrums for someone else to prove, or to toss in the junk heap of discarded ideas. 
Fortunato knew the little porpoise well. "Vaquita", he called out. In English that translates as "little cow." He told us some fishermen called them "duende" or "ghost," a fitting name I thought for a creature so elusive!

"We sometimes catch vaquitas in our gillnets," he told us, but vaquitas aren't worth much in the market." In later years it became clear that such chance captures of the vaquita were so common throughout the heavily fished upper Gulf that, even at the time we first saw them the species was on a precipitous slide toward extinction. That first skull that I had pulled from the sand dune was most likely from a vaquita that died in a fisherman's net.

The general area where we met our first vaquitas, offshore and a bit to the north of San Felipe, is, remarkably enough, even to this day the place where more than $90 \%$ of all the sightings of live vaquitas have been made. No one is totally sure why. Fishermen net them widely over the murky shallow waters of the upper Gulf of California, but that one small area of water is the place where one can almost guarantee actually seeing this rare little porpoise.

What's so special about this vaquita headquarters? Its major feature is a submarine canyon cutting north-south into the otherwise shallow undulating muddy bottom of the upper Gulf of California. Some scientists speculate that this canyon is a remnant of the old channel of the Colorado River, while others say it is a trace of the huge San Andreas Fault that splits off Baja California and much of western Alta California from the North American continent. Probably it's both.

This submarine channel zig-zags past an incongruous, rocky pinnacle, Roca Consag, that juts like a jumbled finger almost vertically out of the otherwise featureless Gulf. The gathering dark found us without fish to tend, so Fortunato maneuvered the San Luis south of the pinnacle. With a seaman's care he dropped the anchor, testing it again and again. The ship stood away to the south, pulling the hauser into a shallow catenary. In the last light we could see the water stream past us, alive and swirling. The hollow barking of a colony of sea lions on the dark rock never ceased.

Emissaries arrived to greet us: an old bull 5 and three calves circled us, leaving rocket trails of cold bioluminescence in the water off the rail of the San Luis. Seabirds swirled by the thousands in the last light, coming to the rock to roost -flights of brown boobies and gulls who settled in silhouette up among the rocks.

Before the tide could turn north and swing us toward the rock we were gone. It was just enough time for Olayo to spraddle across the open hatch and do his stuff, and for the four of us to share a cup with the captain. We watched the bond between the two skippers, Frank and Fortunato, grow. It was built on subtle assessments of each other's competence, and then of respect. Both could read the weather and the currents, and both knew when and where to anchor, and took no chances they could avoid.

Frank's usual admonition was: "Always be afraid of the sea".

Fortunato told us matter-of-factly of his coming to San Felipe a dozen years before. If Mac or I had made the trip he described it would have been a saga to be talked about with wonder from then on. For Fortunato it was just life as he had to live it.

Born of Yaqui Indian parentage in the mountains of Sonora, he had made his way down to the sea as a young man, and then when word of jobs on the rich fishing grounds of San Felipe had reached him, he and a handful of comrades had taken their sole possession of worth, a dugout canoe, and made their way almost 400 miles up and across the Gulf of California at its most treacherous point, the midriff islands, to San Felipe. On charts of those islands one finds rocky promontories with names such as Sal si puedes or "Get out if you can." But Fortunato and his friends made it safely past those waterless desert islands to the promise of jobs at San Felipe.

At San Felipe, Fortunato's calm skill won him his captaincy with the fisherman's cooperative, an organization built around cast-off vessels such as the San Luis.

"What did you do for food and water, Fortunato?" I asked.

"We had tortillas and beans and some bottles of water."

"Did you paddle?"

"Yes, and we used a sail when it took us the right direction," was his reply.

The San Luis's anchor came up and we stood off Roca Consag as the current began to swing around, part of the great sluicing that tips the entire water mass of the Gulf as if on a teeter-totter, with its fulcrum at Guaymas, 300 miles south. This tipping produces enormous tides in the upper Gulf, and boiling currents past Roca Consag.

I began to suspect that the submarine canyon off Roca Consag, the currents, the sea lions, and the birds with their guano, produce a rich piece of water where the little vaquita can find food, and perhaps even a place of surcease from the incessant scraping of the sea bottom by shrimp trawlers. We were told that nearly every inch of the northern Gulf was, at that time, scraped by a trawl about seven times a year. Submarine canyons are no places for nets though; the big spreader boards of otter trawls tend to jam in mud banks, and as surely as if the anchor had been dropped, stop a vessel in its tracks. Worse, if one of the outlying rocks of Roca Consag was to be snagged the net might never surface again.

5 We presume KSN is referring to California sea lions, Zalophus californianus, as they are common in the Upper Gulf. 
Once the word was out that there might be a new cetacean in the Gulf several biologists from both México and the United States began to report possible sightings; an unidentified fin cutting the swift water in an estuary at Guaymas, a group of cetaceans wriggling on a mud bank in shallow water of Topolobampo Bay, fins seen in Bahia La Ventana, down near the tip of Baja California; any or all might have been the little Phocoena. Where did the vaquita live? It took a long time to find out.

In México the focal person was, and still is a remarkable man, Dr. Bernardo Villa Ramirez ${ }^{6}$, long the head of the Department of Mammalogy at the University of México, in México City, and by extension, his many students. I call him Bernardo, because he has become a treasured friend. Bernardo is the heart and soul for the conservation of Mexican wildlands and their life. More than anyone else he has fought to protect every wild thing, from the bats, to the Mexican wolves of the Sierra Madre Occidental, to the whales, seals, manatees, and even the islands of the Gulf of California themselves. To me he is one of the saints in the human struggle to save the wild world, and he includes in his reach the vaquita.

Two U.S. scientists: Dr. Greg Silber, who was a student in my own laboratory at the University of California at Santa Cruz, and who is now with the U.S. Marine Mammal Commission7, and Dr. Robert Brownell, Chief of Marine Mammalogy for the U.S. Fish and Wildlife Service ${ }^{8}$ have led the U.S. effort. Silber and his Mexican colleagues traveled the Gulf widely by boat and plane in order to define the range of Phocoena sinus.

They interviewed fishermen along the length of the Gulf. They sought to discover if these men had dealt with the vaquita or if it was unknown to them. A somber, and to me surprising pattern emerged. The vaquita, they concluded, occupied perhaps the smallest geographic range of any living cetacean. If on the day I discovered that first skull of Phocoena sinus I had turned and clambered up the thousand feet or so to the top of Punta San Felipe I could have looked out across the Gulf of California to Sonora, and north to the delta of the Colorado River, and southeast 50 miles beyond Roca Consag, and I could have seen it all.

Greg and his colleagues defined a range limit across the shallow uppermost Gulf. South of that line almost no one knew about the vaquita, north of it just about every fisherman had seen the little mammal pulled on deck, drowned in the meshes of a net. That's all there is to vaquita country. Their home, Silber his colleagues said, limited to the murky water uppermost Gulf of California.

Silber discovered another thing about the little porpoise that convinced me he was right. He listened to them underwater and recorded their voices. They proved to have what I think of as murky water voices, and, with such an adaptation the only real place for them was where Greg said they were, the murky upper Gulf. To the south of Greg's line the Gulf becomes more and more transparent, and the species of many kinds of life change.

The only sound Greg heard from the vaquita was clicking, given in creaks and long trains, like a rusty hinge. The clicks were incredibly high in frequency- up about nine times as high as an adult human can hear.

How I envision these sounds working goes like this. In muddy water the little porpoise can search for fish with its click trains. The fish can't hear the high frequency sounds of the porpoise. Apparently the primitive hearing mechanisms of most of them aren't good for sounds even a tenth that high. The water is too dirty for the porpoise to be seen by eye for more than a couple of yards, at best. By the time the porpoise comes that close a fish has no time to react. Lunch.

Because no other sea animal, except some other cetaceans, make sounds of such high frequencies it might also be that the little porpoises can locate each other and carry on their society without fear of detection.

Greg and I also hoped that this acoustic circumstance might provide a way for biologists to detect the presence of porpoises that couldn't be seen at the surface. We might then try to listen throughout the upper Gulf with gear sensitive to such high frequencies. By plotting where each sound contact it might be possible to make an accurate acoustic count of vaquitas. If the method worked it could provide an accurate assessment of how many vaquitas remain alive, and where, exactly, they ranged.

While our attempts at plotting their occurrence by listening were not successful due to the high cost of obtaining the proper equipment, another scientist, Jonathan Gordon, of Great Britain has made the method work for the Queen's porpoises, and I hope it will soon be applied to the vaquita to tell us just how many survive.

So, rare the vaquita certainly is. Only forty-two years after I put that first skull in its cardboard carton the vaquita is now sometimes given the dubious distinction of being called the world's most endangered cetacean. It vies for this unwelcome crown with two river dolphins, the Indus River Dolphin of Pakistan, and the Baiji of the Chang Jiang (Yangtze) River of China, each species likely comprised of less than 400 living individuals?.

The vaquita has been classed as "endangered" by the International Union for the Conservation of Nature", the organization who maintains the authoritative "Red Data Book," that keeps track of the world's endangered wildlife.

\footnotetext{
Villa Ramirez passed away in 2006, after an amazingly productive career.

Silber was later with the NOAA Fisheries, and is now retired.

Brownell is now with the NOAA Fisheries' Southwest Fisheries Science Center.

Unfortunately, the baiji is considered to have gone extinct in around 2006. The Indus River dolphin, however, is doing better than KSN thought, currently numbering about 800 individuals.

10 The IUCN currently classifies the vaquita as Critically Endangered.
} 
In truth, no one knows how many vaquitas there are. They are shy little animals, and only when the sea is calm is there much hope of seeing them. Yet, the upper Gulf is a very small piece of not very remote ocean. The thirty or so that are caught each year in fishing nets seem clearly more than the species can stand for verylong.

I have yet to stand looking at a fresh-caught vaquita; yet I know what the species looks like from the few photographs that have been taken, some by Flip Nicklin. It is a roly-poly little animal, the tall fin and big pectoral flippers are there, alright. It looks as if it wears a pair of dark sunglasses; a big round blotch of black skin surrounds each eye. It has a wide-eyed look about it, as if it easily placed its fate in our hands. Its tiny little babies are marked with vertical bands of light grey from the time when they lay curled in their mother's uterus, and like many baby mammals they are all dependence and innocence. The fate of the vaquita, adults and young is, in fact, wholly in our hands. As I wrote this, word came from Greg Silber that the government of México, through the good grace of President Salinas himself, has established a preserve on behalf of the vaquita and the totoaba including the entire upper Gulf of California. See the fine hands of my various colleagues in this.

Hang in there, vaquita. It might just work... 